\title{
Models of Regulation as Tool for Risk Elimination in Network Industry Markets in Slovakia
}

\author{
Eleonora Fendekova ${ }^{1^{*}}$ \\ ${ }^{1}$ University of Economics Bratislava, Department of Business Economics, Dolnozemská cesta 1/b, \\ 85235 Bratislava, Slovakia
}

\begin{abstract}
In Slovakia in the recent period of time we have seen an intensive discussion concerning the effectiveness of the price regulation methods in Network Industries and the objectivity and the labour social effectiveness of The Regulatory Office for Network Industries, as well. It is understandable as network industries in fact ensure the production and distribution of energy sources which play a key role in an effective operation of the developed economies. The discussions are usually focused on the question of a reasonable profit of the network industries companies and on the other hand on the question of prices which are determined by the reasonable and generally acceptable costs of their production. In relation with objectification and increases in nationwide operation effectiveness of natural monopolies in network industries ${ }^{\dagger}$ on the market the role of regulation mechanisms is increasing. Its aim is the closest approximation of proportions between price and level of network industry products supply to the situation which would occur in the conditions of market competition. In the paper we will analyze analytical scheme for monopoly price regulation - rate of return regulation.
\end{abstract}

\section{Introduction}

Modern market structures in economically developed countries are generally represented by imperfect competition. We need to realize, that monopoly, in consequence of its exclusive market position as a sole supplier of commodity or service on the relevant market, can set the market price and supply any level of production, which allows it to maximize profit above the level of capacity of competitive company.

\footnotetext{
* Corresponding author: eleonora.fendekova@euba.sk
}

$\dagger$ Under network industries in terms of Slovak Republic in accordance with Act No. 276/2001 Coll. on Regulation in Network Industries we understand the following industries

1. generation, transmission, distribution and supply of electricity and the related services

2. production, transport, distribution, storage and supply of gas and the services related to these activities

3. production and distribution of heat

4. water management and mass conduct of sewage by a public sewage system 
Blum, Müller and Weiske [2] show, that monopoly is, of course, acting within the legitimate market conditions and its position is determined by the real market situation. On the other side it is natural for such means to exist, which allow redistribution of this profit in a way that part of it would support nationwide economy development objectives of the country it is operating in.

In principle, there are two schemes, which can be applied by the state in regulation of monopoly price policy.

a) Taxation of monopoly

There is a potent tool at states disposal to regulate the development of market equilibrium conditions on monopolistic market. It is a tax policy. In a simplified way, we can tell that the state is redistributing the profit of monopolistic firm through its taxation. This process of taxation in the imperfect competition environment has, in comparison with perfect competition environment, certain specificity.

Firm operating in perfect competition environment can respond to enforcement of particular scheme of tax burden only by modifying the amount of goods supplied on the market. Fendek and Fendeková [6] show, that monopoly has, however, broader room for decision making because in its competence there is not only setting the amount of goods supplied on the market but also, after taking into account consumer behavior, setting the price of good on relevant market.

b) Application of specific regulatory mechanisms affecting behavior of natural monopolies

In Rode [10] we can see, that or the regulation of subjects of the chosen industries, which are in light of their market share monopolies or natural monopolies, the state is creating institution, so-called regulator, which task, under the state authority, is to create such legislative environment and regulatory mechanisms, which will ensure market equilibrium for observed commodities while granting fair profit for regulated subject. Among these industries particularly belong network industries, which subjects often share characteristics of monopolies and state has therefore desire to regulate them.

\section{Means of state to regulate price policy of monopoly}

In Slovak conditions the role of the regulator is represented by Regulatory Office for Network Industries (RONI), which role is to issue licenses, regulate prices and quality norms for network industry products. Regulatory offices in relation with fulfilment of their main mission - technical and price regulation of enterprise in regulated activities of chosen industries - are facing the effective solution of two tasks:

(1) Preparation of working and, this needs to be stressed, competitive market environment for network industries goods while applying standard regulatory mechanisms, mainly in context of Slovak entry into the EU and gradual adaptation of Slovakia to the conditions on energy markets of united Europe;

(2) Preparation of such analytical apparatus for network industries price regulation, which would guarantee effective development of regulated subjects. In the first period it was equally important to eliminate deformations in prices of network industries products.

A need of the particular legislation of regulatory framework for natural monopolies in Slovakia has arisen in the beginning of 1990s. Legislation in this period has not been covering the whole area of regulation therefore in 1993 the Antimonopoly Office of the Slovak Republic prepared a bill for regulation of natural monopolies, which assumed delegation of powers to a single body. This proposal should have supported companies by stimulating competitive environment towards greater effectiveness and reaching better quality levels. 
Regulation, according to this proposal, should have been related to generation, transfer and distribution of electricity, heat, gas, water, but also telecommunications. Subjects of regulations should have become prices, tariffs, expenses, trade conditions and entry to the market in form of issuing licenses. Bill on regulation of natural monopolies was worked out in two alternatives from the perspective of founding and status of the regulatory bodies.

First alternative considered founding of four independent regulatory offices, financed from the revenues of regulated subjects. The aim was to create basis for high expertise, objectivity and stability of regulatory system. Second alternative considered that agenda of regulatory office would be performed by central body of the state administration set by the government.

Regulatory office oversees following of obligation to provide a third party with access to the networks and adjudicates disputes. Obligation to provide a third party with network access is also related to full opening of the internal energy market and to consumer option to freely choose energy supplier. According to this, RONI regulations are limited to activities with natural monopoly character only, that is, prices or tariffs set by the office will not include any unregulated items.

In order for Regulatory office to meet this objectives it should be financially and personally independent from executive body for reasons of transparency. Additionally regulatory powers to pass mandatory regulatory statues must be at its disposal. It also needs virtue to enforce them.

RONI is carrying out regulation through the use of standard, in developed economies proven methods. Details about price regulation process in network industries and determination of scope of justified costs and reasonable profit are enacted by the office in office decrees, which are published in Collection of Acts, in Office bulletin and on the website of the office.

Efficient functioning of commodity and service market in network industries in conditions of Slovak republic can be insured only by quality and potent regulatory policy in the context with the Slovak Republic law and respecting the adopted legal acts of European Community and European Union. All consumers, with emphasis on "vulnerable" groups, mainly households, must have an opportunity to make use of high level consumer protection, referring mainly to households, while maintaining adequate guarantees and suitable incentives for regulated subjects.

\section{Analytical Methods for network industries regulation}

In Waldman, and Jensen [13] we can see, that traditional methodological tool for price regulation applied by price regulators to set maximum price of network industries products is the regulation on the basis of the rate of return - Rate of Return Regulation, by which are the prices of electricity, gas and other companies regulated in the most of the developed countries.

The aim is to ensure that the regulated entity will set the price of commodity or service for its consumers in a way the revenues will cover all its reasonable and provident costs incurred as well as regulated return on its provident investment.

Let us now analytically derive the allowable rate of cost return for investment, co called $R o R$ parameter of the regulated entity. Let us suppose that the firm is producing a

\footnotetext{
¥ It should be noted, that under term provident we understand situations, when certain decision about investment or expenditures has been made in conditions of verified and relevant information available in the time of decision making.
} 
homogenous product in production volume $q$, which it realizes on a relevant market for the price $p$. Let us further suppose that the firm uses two production factors, namely labor force with consumption level $L$ by labor price $w$ and the capital with consumption level $K$ by the capital price $r$.

The profit of the firm is generally defined as the difference between the yields and costs

$$
\pi(q)=t(q)-n(q)
$$

where

$t(q)=p \times q-$ function of revenues of the firm, $t: R \rightarrow R$

$n(q)=n v(q)+n f-$ function of the total costs of the firm, $n: R \rightarrow R$

$n v(q)$ - function of the variable costs of the firm, $n v: R \rightarrow R$

$n f$ - fixed costs of the firm, $n f \in R$

If we substitute general cost function on the basis of consumption of production factors, we get a profit function in a following form

$$
\pi(q)=p \times q-w \times L-r \times K
$$

If we further express the production volume $q$ on the basis of the production function in the form

$$
q=f(K, L)
$$

and the production price $p$ on the basis of the price-demand function in the form

$$
p=p(q)
$$

then we can express the profit function in the form

$$
\pi(q)=p(q) \times q-w \times L-r \times K
$$

and after further modification in the form

$$
\pi(q)=p(f(K, L)) \times f(K, L)-w \times L-r \times K
$$

Fendek and Fendeková [4] show, that a non-regulated firm can set its endogenous decision parameters in any way. So it chooses an optimum output volume $q^{*}$, an acceptable optimum price $p^{*}$ and corresponding consumption levels of the production factors labor $L$ and capital $K$ in a way to reach maximum profit. Optimum output and optimum price will be calculated by solving the following mathematical programming task

$$
\begin{gathered}
\pi(q)=p(f(K, L)) \times f(K, L)-w \times L-r \times K \rightarrow \max \\
K, L \in R_{\geq 0}
\end{gathered}
$$

In this case the non-regulated firm has no formal boundaries for setting the parameters guaranteeing its maximum profit. On the other hand, the regulated firm must respect boundaries given by the regulator. Price regulation regime on the basis of the rate of return lies in a fact, that through the use of exogenously defined control variable $R o R$ the allowable level of quotient of the revenues $p \times q$ reduced by its non-capital expenditures $L \times w$ and the volume of consumed capital $K$ is regulated.

In other words, a firm can optimize or freely determine the consumption levels of labor $L$, capital $K$ by the market prices of production factors $w, r$ and on the other side the level of its production $q$ but also the production price $p$. However firm has to respect the rate of return defined by the regulator i.e. the validity of the relation

$$
R o R \geq \frac{p \times q-w \times L}{K}
$$


Let us further in detail explore the relation between the rate of return of the capital expenditures and the profit of the regulated entity. Profit can be analytically expressed as the difference between the proceeds and the costs of the firm in the form

$$
\pi(q)=p \times q-w \times L-r \times K
$$

Let us deduct the price of the capital $r$ from the both sides of the relation (1). We get the relation

$$
R o R-r \geq \frac{p \times q-w \times L-r \times K}{K}
$$

From the comparison of the relation (2) and (3) we get the relation

$$
(R o R-r) \times K \geq z(q)
$$

From the relation (3) we can see that the regulated entity can set its system parameters only in a way that profit it reaches will not exceed the value of the capital evaluated by the difference between the rate of return $R o R$ defined by the regulator and the price of the capital $r$.

Regulated entity can set its controlled (endogenous) decision parameters only in a way respecting regulatory condition. It sets the regulated volume of output $q_{R}$, the acceptable regulated price $p_{R}$ and the corresponding consumptions of production factors labor $L$ and capital $K$ in a way to reach maximum profit while respecting regulatory conditions (3) about non-exceeding the reasonable level of profit. The regulated output and regulated price are calculated by solving of the following mathematical programming task

$$
\pi(q)=p(f(K, L)) \times f(K, L)-w \times L-r \times K \rightarrow \max
$$

by the boundaries

$$
\begin{gathered}
p(f(K, L)) \times f(K, L)-w \times L-r \times K-(R o R-r) \times K \leq 0 \\
K, L \in R_{\geq 0}
\end{gathered}
$$

Solution of this optimization task is optimum consumption level of production factors labor $L^{*}$ and capital $K^{*}$. On their basis with the help of production function the regulated optimum level of output $q_{R}{ }^{*}$ is quantified according to the following form

$$
q_{R}^{*}=f\left(K^{*}, L^{*}\right)
$$

and regulated optimum price $p_{R}{ }^{*}$ with the help of price-demand and production function on the basis of the relation

$$
p_{R}^{*}=p\left(q_{R}^{*}\right)=p\left(f\left(K^{*}, L^{*}\right)\right.
$$

While respecting the rate of return on capital defined by the $R o R$ parameter, i.e. exogenous parameter set by the regulator.

In the situation when the firm would not be regulated and had an exclusive position on the relevant market it would choose such optimum volume of consumption of variable inputs labor $L^{*}$ and capital $K^{*}$, to ensure maximum profit. On the basis of optimum consumption of variable inputs it would set its optimum supply volume and optimum price of production

$$
p^{*}=p\left(q^{*}\right)=p\left(f\left(K^{*}, L^{*}\right)\right.
$$

In the case the firm is regulated, it can only choose the combination of input factors in such a way the corresponding production volume and price of production would generate reasonable profit i.e. to adhere to this form

$$
(R o R-r) \times K \geq p(f(K, L)) \times f(K, L)-w \times L-r \times K
$$




$$
(R o R-r) \times K \geq \pi(q)
$$

Thus the regulated firm can produce in a manner that its reasonable profit does not exceeds $R o R-r$ multiple of the variable capital input volume. This condition is called reasonable profit margin of the regulated firm. It is obvious that in case when the regulator sets rate of return on capital $R o R$ in a way it will exceed its cost $r$, the firm reaches positive profit for any combination of inputs of production factor $K$ with positive volume. This statement predicates the problems of exclusive position of production factor capital on decision making of the regulated firm.

However this form of price regulation is hiding one serious risk. It often motivates firm to use higher volume of variable input capital than non-regulated firm.

We can show, that firm can produce regulated production volume $q^{*}{ }_{R}$ with any combination of variable inputs labor and capital corresponding to isoquant $q^{*}{ }_{R}=f(L, K)$. Barthwall [1] show, that if the regulation on the basis of the rate of return stimulates firm towards using large volumes of capital in order to reach maximum profit allowed, the firm is not motivated to use often more effective and from the point of view of production price and production volume of inputs equivalent combinations of inputs localized on isoquant (e.g. supporting employment) in comparison with purposeless investments into the equipment. However there are also other, more sophisticated examples of cost structure of the firm.

\section{Conclusion}

The aim of this paper was to analyze the effects of network industries price regulation from the point of achieved level of reasonable profit of the regulated entities.

On the basis of the firms behavior in the conditions of the rate of return on capital regulation we show that in this regulatory scheme the firm has the tendency to respond to the tightening of the regulatory conditions by increasing the volume of used capital. Increase of used capital volume is, however, not the goal that the regulatory system is following. Regulation aims to influence others, for the firm and for the economy more important indicators, such as the volume of production, level of sales or the volume of costs.

Therefore other price regulation forms were developed to influence regulated firm reasonable profit on the basis of its total costs. The aim is, with the help of the regulatory mechanisms, to encourage effective development of the regulated entity.

On the basis of the economic development analysis, we can state that the applied regulatory methods have not only the stabilizing effect in the network industries market environment but also the motivational aspect for the effective development of the regulated entities.

\section{References}

1. Barthwal, R.R., Industrial Economics. New Delhi: New Age International, 545 s. ISBN 81-224-1278-5 (2010)

2. Blum, U., Müller, S., Weiske, A., Angewandte Industrieökonomik. Theorien - Modelle - Anwendungen. Berlin: Verlag Gabler (2006)

3. Bodea, T., Ferguson, M., Segmentation, Revenue Management, and Pricing Analytics. New York and London: Routledge (2015). Carlton, D.W., Perloff, J. M., Modern Industrial Organization. Boston: Addison Wesley (2005) 
4. Fendeková, E., Fendek, M., Mikroekonómia: Oligopoly a regulované monopoly. Bratislava: Wolters Kluwer, p. 230, ISBN 978-80-8168-765-5 (2018)

5. Fendek, M., Fendeková, E., Modely cenovej regulácie siet’ových odvetví. Ekonomický časopis: časopis pre ekonomickú teóriu a hospodársku politiku, spoločenskoekonomické prognózovanie. Bratislava: Ekonomický ústav. vol. 48, no. 10, pp. 1039 1055. (2010)

6. Fendek, M., Fendeková, E., Models of regulation of network industries in Slovakia. In: International journal of economics and business research. - UK : Inderscience Enterprises Ltd, vol. 1, no. 4, pp. 479-495 (2009)

7. Fendek, M., Fendeková, E., Cost-oriented models of network industries price regulation. In: Operations research proceedings, selected papers of the Annual international conference of the German operations research society (GOR) University of Augsburg, September 3-5, 2008. - Berlin: Springer Verlag, pp. $73-78$ (2008)

8. Meehen, J. M. et al., Pricing and Profitability Management. Singapore: John Wiley \& Sons (2011).

9. Pepall, L., Richards, D., Norman, D., Industrial Organization: Contemporary Theory and Empirical Applications. New York: Wiley-Blackwell (2008)

10. Rode, S., Modern Microeconomics. Ventus Publishing, 231 p. ISBN 978-87-4030419-0. (2013)

11. Sherman, R., The regulation of monopoly. Cambridge university press. Cambridge (1990)

12. O'Sullivan, A., Sheffrin, S., Perez,P., Microeconomics: Principles, Applications, and Tools (New York: Prentice Hall) (2006)

13. Waldman, D. E., Jensen, E. J., Industrial Organization: Theory and Practice. New York: Addison Wesley (2006) 